\title{
Fostering embracement, inclusion and integration of migrants in complex migration situations: A perspective from Matthew 25:31-46 and Hebrews 13:1-2

\begin{tabular}{|c|c|}
\hline \multicolumn{2}{|c|}{$\begin{array}{l}\text { Authors: } \\
\text { Alfred R. Brunsdon }{ }^{1} \text { (1) } \\
\text { Christopher Magezi }{ }^{2} \text { ( }\end{array}$} \\
\hline \multicolumn{2}{|c|}{$\begin{array}{l}\text { Affiliations: } \\
\text { 'Department of Practical } \\
\text { Theology, Faculty of } \\
\text { Theology, North-West } \\
\text { University, Mahikeng, } \\
\text { South Africa }\end{array}$} \\
\hline \multicolumn{2}{|c|}{$\begin{array}{l}{ }^{2} \text { Department of Practical } \\
\text { Theology, Faculty of } \\
\text { Theology, North-West } \\
\text { University, Vanderbijlpark, } \\
\text { South Africa }\end{array}$} \\
\hline \multicolumn{2}{|c|}{$\begin{array}{l}\text { Corresponding author: } \\
\text { Alfred R. Brunsdon, } \\
\text { alfred.brunsdon@nwu.ac.za }\end{array}$} \\
\hline \multicolumn{2}{|c|}{$\begin{array}{l}\text { Received: } 20 \text { Feb. } 2020 \\
\text { Accepted: } 26 \text { June } 2020 \\
\text { Published: } 28 \text { Aug. } 2020\end{array}$} \\
\hline \multicolumn{2}{|c|}{$\begin{array}{l}\text { How to cite this article: } \\
\text { Brunsdon, A.R. \& Magezi, C., } \\
\text { 2020, 'Fostering } \\
\text { embracement, inclusion and } \\
\text { integration of migrants in } \\
\text { complex migration situations: } \\
\text { A perspective from Matthew } \\
\text { 25:31-46 and Hebrews } \\
\text { 13:1-2', HTS Teologiese } \\
\text { Studies/Theological Studies } \\
76(2) \text {, a5966. https://doi. } \\
\text { org/10.4102/hts.v76i2.5966 }\end{array}$} \\
\hline \multicolumn{2}{|c|}{$\begin{array}{l}\text { Copyright: } \\
\text { (c) 2020. The Authors. } \\
\text { Licensee: AOSIS. This work } \\
\text { is licensed under the } \\
\text { Creative Commons } \\
\text { Attribution License. }\end{array}$} \\
\hline \multirow[b]{2}{*}{ 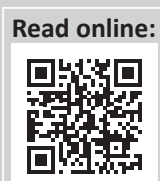 } & \\
\hline & $\begin{array}{l}\text { Scan this QR } \\
\text { code with your } \\
\text { smart phone or } \\
\text { mobile device } \\
\text { to read online. }\end{array}$ \\
\hline
\end{tabular}

This article identifies the complexities of migration situations that subject both host nations and native churches to a paradoxical position on whether to exclude or embrace migrants. This is because migrants are often linked to criminal activities that threaten citizens of the host country. In response to the perceived challenge, this article investigates Matthew 25:31-46 and Hebrews 13:1-2 to propose that the church as a community of God is not supposed to take a paradoxical stance in the complex situation of migration. This is because the church is a community of God that is divinely ordained to embrace and care for the vulnerable regardless of their faith, religious and ethnic backgrounds. The church is thus obliged to continuously carry out its compassionate and caring mandate for the vulnerable despite the possible challenges incurred.

Contribution: The article contributes to the ongoing theological reflection on the challenges posed by migration with special reference to the church as faith community. It is aimed at stimulating practical theological thinking regarding human displacement by critically reflecting on the current ministry of the church in light of Scriptures with regards to migrants.

Keywords: Complex migrant situations; Migrant ministries; Vulnerable people; Inclusion; Matthew 25:31-46; Hebrews 13:1-2.

\section{Introduction}

The jailing of a Congolese migrant leader, who had taken refuge at the Central Methodist church in Cape Town on New Year's Day 2020, brought the interest of the authors of this article into graphic focus. ${ }^{1}$ On the one hand, it reminded us of the churches' hospitable embracement of migrants ${ }^{2}$ in some parts of the country, and, on the other hand, it brought our attention to the perception that migrants are associated with unlawful behaviour, which puts their relationship with the church under growing pressure.

This strained relationship between the church and migrants was illustrated more clearly towards the close of 2019 when the Mail and Guardian reported on the alleged assault on religious leaders and human rights officials (Kiewit 2019):

Faith leaders including Anglican Archbishop Thabo Makgoba and South African Human Rights Commissioner (SAHRC) Reverend Chris Nissen have allegedly been assaulted by refugees currently occupying the Greenmarket Square Methodist church in Cape Town. (n.p.)

Comparing the above scenario to a 'hostage situation' (Kiewit 2019) further portrays migrants in a negative light and strengthens their stereotyping as a growing criminal element in the country. This stereotype is reinforced by inflammatory remarks from prominent figures such as Gauteng Provincial Police Commissioner Lieutenant-General, Deliwe de Lange, who stated in 2017 that 'about $60 \%$ of [the] suspects arrested for violent crimes in the province were illegal immigrants' (Van Lennep 2019).

Unfortunately, the label 'criminal' is not the only stereotype ascribed to migrants, as they are generally associated with putting the already dire South African economy under further pressure,

1.Media reports in, amongst others, The South African (01 January 2020) and News24 (01 January 2020), on the 1 st of January 2020 stated that a Congolese refugee leader was arrested after allegedly assaulting fellow refugees staying at the Central Methodist Church in Cape Town. Please see the notes in the references. 
stealing job opportunities from South African nationals and downgrading the good work standards in the country (Van Lennep 2019). This kind of stereotyping is generally regarded as the root cause of the xenophobic violence that regularly flares up in the country.

This scenario presents difficult questions to the church, which, as a Christian institution, has over the years shown sympathy towards migrants in many parts of the country and in different ways. Consequently, a number of questions can be posed. Such questions include should the church persist with sympathy and care? Should the church continue to offer refuge to people shrouded in suspicion and tax their hosts with many challenges and burdens? Should the church not rather side with the growing number of South Africans who are showing a negative attitude towards migrants and become part of the movement that sees the deportation of migrants as the best solution to the phenomenon of xenophobia (Coetzee 2019)? For pastoral care that is based on 'sacrificial ethics and the agape-principle of unconditional love', Louw (2016:2) feels that these types of questions are 'severe and critical'. On a deeper level, it raises the question whether a selective approach that excludes migrants because they are perceived to be dangerous is still within the 'parameters of a theology of compassion?' (Louw 2016:2).

This article will lean towards the stance that the church, because of its essence as the body of Christ and the stark realities of migration, does not really have a choice other than persisting in sympathy and care for the desolate. By contemplating the matter from a practical theological paradigm, which is concerned with critical reflection about the practices of the faith community in the light of the Word, the focus will be on the growing reality of migration, a deconstruction of the stereotype of migrants as criminals and an analysis of Matthew 25:31-46 and Hebrews 13:1-2 to foster embracement, inclusion and integration of migrants in a complex migration situation, as alluded to in the foregoing section.

\section{The growing reality of migration}

It is incontestable that migration is one of the major challenges of our time. The escalating movement of people from one region to another is fuelled by aspects such as globalisation and improved technological advancement (Lid’ák 2014:226; Martin 2008:1-6; Monsma 2000:13-14). Cuterela (2012:137) defines the term globalisation as the emerging of an international network, belonging to an economic and social system'. As a major cause in the growth of international migration, globalisation is aided by new technologies in communication and transport systems (Cuterela 2012:137147). Communication technologies include radio, TV, the Internet, email and social media such as Facebook and WhatsApp (Cuterela 2012). These communication technologies establish social and cyber networks that make people aware of work, entertainment and business opportunities in other countries. New means of transport such as air, sea, road and railway transportation ${ }^{3}$ make it easier for people to move both locally and internationally (Organisation for Economic Co-operation and Development [OECD] n.d.:1-8; Sturm-Martin 2014:4).

In this climate where people are constantly on the move, the African continent also shares the burden of inter-regional migration. It seems that Africans, first and foremost, cause each other to be dislocated as a result of ethnic, religious or political conflict. Onaedo, Samuel and John (2017:21) suggest that there are currently more Africans who are displaced as a result of intrastate wars, than by interstate or international conflict. In the bigger African picture, South Africa, because of the absence of civil war, is viewed by many as a desirable destination that offers more hope for a stable home than many other parts of Africa. South Africa is made an even more desirable destination because it boasts of some of the world's most progressive rights for asylum seekers and refugees that allow them to settle, work and study anywhere in the country (Amit 2017:1). Arguably, this has caused South Africa to be the top recipient of asylum seekers for 6 years in a row, prior to the dawn of the Syrian crisis (Amit 2017:1). Even after being dethroned from that position, it is estimated that South Africa currently hosts more than 268000 refugees and asylum seekers (Shoba \& Tobias 2019). This number refers to persons who applied for refugee status in South Africa after seeking asylum as a result of experiencing lifethreatening circumstances in their previous countries of residence. According to statistics, the numbers of foreign nationals inclusive of all types of immigrants in South Africa are much higher than refugee and asylum status applicants. As of 2016, South Africa hosted an immigrant population of approximately 2.8 million (Heleta 2018).

These numbers render the phenomenon of migration one of the grave realities of our time on both global and national scales. This reality is not set to disappear by any means in the foreseeable future, but rather calls for a need to face the dilemma in a humane and realistic way.

\section{A deconstruction of the stereotype of migrants as criminals}

As alluded to earlier, migrants are stereotyped in many different ways by their host communities. In South Africa, this stereotyping mainly revolves around perceived economic and criminal challenges. The association between migrants and criminal activities is, unfortunately, not completely coincidental, but rooted in incidents where observers linked migrants to specific unlawful acts. Research studies by Pluncinska (2015:n.p.), Louw (2016:1-3) and Magezi (2018:211-213) highlight the involvement of some international migrants in criminal activities. These authors

3.We are aware that, currently, some people are still using some crude and dangerous modes of sea transport, which result in many of them failing to reach desired modes of sea transort, which result in many of them failing to reach desired countries of destinations, as they perish during the migration process. Greene (2016), a CNN news reporter, substantiates the foregoing notion as he advises that the year of 2016 witnessed an increment of approximately 3800 Syrians, Afghan and Iraqis drowning in the Mediterranean Sea as they tried to escape from wars in their countries. Most migrants from war-torn countries are left with no choice, but to sail to the other parts of the world using 'rickety boats' of smugglers that 'should never have sailed' (Greene 2016:1). 
note the Paris Massacre 4 of the 13 November 2015, as an example of incidents that triggered European nations to be wary of migrants. Although Pluncinska (2015) challenges the legitimacy of such suspicion, it is doubtless that the Paris killings triggered some mixed feelings and reactions amongst many European nations. For instance, because of the Paris Massacre, European nations such as France, Italy and Belgium tightened their border security as a means of denying Syrian refugees access into their borders (Pluncinska 2015). Also, many other European countries, such as Slovakia and the Czech Republic, which linked the Paris Massacre to the Syrian refugees (Pluncinska 2015):

$[W]$ ere already sceptical of accepting refugees in the first place, arguing that it would be difficult to integrate Muslim migrants into their societies and citing fears that terrorists could cross their borders. (n.p.)

Although in South Africa, migrants have not been suspected or accused of terrorist activities, a definite association between them and criminal activities surfaces regularly. The alleged involvement of migrants in violent crimes in certain parts of the country is one example of the popular perceptions and unfortunate stereotyping of migrants (Van Lennep 2019). However, a growing number of observers call for a deconstruction of these negative stereotypes, as they only work towards engendering xenophobia, which worsens the migration dilemma instead of yielding sustainable solutions to this global crisis.

Although positing that the media and government officials are the first line in such a deconstruction, Heleta (2018) pleads for more realistic reporting on the statistics of foreign nationals in South Africa. An over-reporting of, at times, more than 2 million above the official figures, creates a sense of panic and overwhelms the local population, leading them to blame migrants for local deficits, such as the high crime rate.

In the same vein, Van Lennep (2019) pleads for more realistic reporting on crimes in which migrants are implicated. Putting the unfortunate link between violent crime in South Africa and migrants in perspective, Van Lennep (2019) indicates that the number of foreign nationals currently in South African jails is a very small proportion of the population they constitute, meaning that the rate of crime committed by migrants is lower than that committed by the local populace.

The greatest appeal for the deconstruction of the negative stereotypes harboured about migrants, however, should be made to the general public. Reacting to findings of the Human Sciences Research Council (HSRC) on prejudice suffered by migrants in South Africa, Coetzee (2019) reports:

It would appear that the majority of South Africans hold very negative views about the impact of international migrants on

4 Kenya (a sub-Saharan African nation) experienced many killings in the past years, which a buber line which were linked to Somali refugees. In response, the Kenyan government tightened its security at the border posts and she was criticised (cf. the Human Rights Watch 2014). However, the main challenge hosting nations are facing is that, in trying to be hospitable, they end up being under threat.
South African society in which a significant share of the public believes that immigrants are a major driver of unemployment and crime. (n.p.)

Ascribing these negative views mainly to prejudice and the lack of proper programmes of integrating migrants into the local population, it is evident that South Africans need to deconstruct the perceptions of foreign nationals that they nurture.

Because these perceptions and stereotypes have become firmly rooted in society, the church is reminded of its own calling to be a spiritual community that is sanctioned by the Lord to respond in an alternative way to the needs of the vulnerable, such as migrants. This is the call which is rendered in both the Old and New Testaments (cf. Ex 22: 21-27, 23:9; Lv 19:33-37; Dt 24:14-22, 10:12-22; Mt 25:31ff). In other words, the church, as God's representative in the world, should reflect the God's loving and compassionate character to those that are marginalised or vulnerable in their societies (Magezi 2019:1). Unlike the world, the church should persist to show compassion regardless of the possible challenges that it encounters in this process (Louw 2016:2; Magezi 2018:335).

In this regard Matthew 25:31-46 and Hebrews 13:1-2 are of interest for this article, as it seems to focus on the role of Christians towards the vulnerable. Irrespective of the seemingly radical commands of these passages, they are important in the search for an authentic theological response to the migrant challenge. Although the focus of Matthews is on the way the vulnerable should be treated, their identity and the importance of this call for authentic Christianity, Hebrews provides a perspective on the importance of staying true to the Christian calling irrespective of challenges the Christian might experience.

\section{Matthew 25:31-46 and the treatment of vulnerable people}

A number of scholars (cf. Hood 2009:527-543; Morris 1992:639; Turner 2008:610) consider Matthew 25:31-46 as a parable that Jesus tells his disciples about the ultimate judgement. This parable is part of Jesus' last address to his disciples (Mt 24:1) before he accomplishes redemption for humankind through his suffering, death and resurrection, as depicted in the wider context of Matthew 26-28:15. Jesus' final speech to his disciples commences in Matthew 24-25 and concludes in the parable of the eschatological judgement of all people (Mt 25:31-46) (Morris 1992:639; Turner 2008:610). In this eschatological judgement, the believer's treatment of the fellow human beings serves as an ethical framework.

In discussing this passage, we will initially establish the identity of those that are gathered and judged by the Son of Man (Jesus Christ) (Mt 25:31-32a), the basis of the judgement 
and its consequences to those found to be righteous or unrighteous (Mt 25:33-46). The focus will then shift to the meaning of the least of these brothers and sisters of mine (Mt 25:40) and the least of these (Mt 25:45) because it is crucial in determining the interpretation and application of the entire passage (Zhang 2016:17).

\section{The identity of those that will be gathered and judged by the Son of Man in the final judgement: Matthew 25:31-32}

In determining the meaning and application of Matthew 25:31-46, the meaning of all nations ( $\pi \dot{\alpha} v \tau \alpha \tau \dot{\alpha} \dot{\varepsilon} \theta v \eta$ ) that will be gathered before the throne of the Son of Man in Matthew

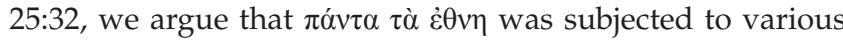
interpretations through history (Gray 1989:347; Luz \& Koester 2005:274ff). Gray (1989:8-9), who provides a historical analysis of Matthew 25:31-46, identifies the following interpretations of $\pi \alpha ́ v \tau \alpha \tau \grave{\alpha} \dot{\varepsilon} \theta v \eta$. Firstly, from a Jewish perspective, all nations refer to all gentiles (Gray 1989).

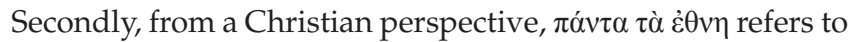
non-Christians (Gray 1989). Thirdly, from its widest possible

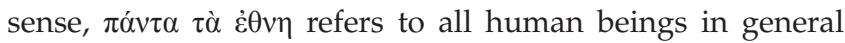
(Gray 1989).

Notably, Brown (2016:15-16) argues that the interpretation of $\pi \dot{\alpha} v \tau \alpha \tau \grave{\alpha} \dot{\varepsilon} \theta v \eta$ (all the nations) to mean all human beings in general has been widely accepted in the scholarly guild, and this interpretation is also termed the universalist interpretation. However, because the other interpretations identified by Gray (1989:8-9) are less dominant in the current scholarship, this does not mean that no other scholars subscribe to them. For instance, Claeys (2017:57-58) recently subscribed to the interpretation of $\pi$ óv $\tau \alpha$ $\tau \dot{\alpha} \dot{\varepsilon} \theta v \eta$ to mean 'all gentiles'. However, a considerable number of scholars (Morris 1992:639; Newman \& Stein 1988:781; Turner 2008:610; Van Zyl 2013:115-118) subscribe to the universalist

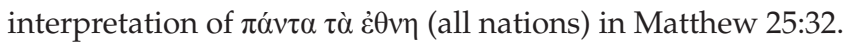

Representative of the universalist interpretation of $\pi \alpha \dot{v} \tau \alpha \tau$ ì $\dot{\varepsilon} \theta v \eta$, Van Zyl (2013:115-118) argues that this interpretation rests on the internal logic of Matthew's gospel. Van Zyl argues that although Matthew 24:14 proclaims the coming of the end after the evangelisation of all the nations, Matthew 25:3-46 also refers to the judgement of all nations. In linking Matthew 24:14 and Matthew 25:31-46, Van Zyl

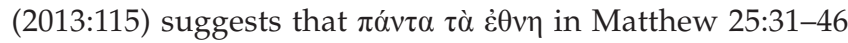
includes all people because the entire world will have already been evangelised at that time. In substantiating this, Van Zyl brings Matthew 28:18-20 to bear in this conversation. He observes that, although Matthew 28:18-20 comes after Matthew 25:31-46, it is apparent that from a Christological dimension, Matthew 25:31-46 should be placed after Matthew 28:18-20, in which Jesus' disciples are commanded and commissioned to preach the gospel to all nations ( $\pi \alpha$ viva $\tau \grave{\alpha} \dot{\varepsilon} \theta v \eta)$. In placing Matthew 28:18-20 before Matthew
25:31-46, Van Zyl (2013:115) perceives the command of Matthew 28:18-20 to have already been fulfilled by the time of the final judgement of all nations (in Mt 25:31-46), so that no human will be ignorant about the will of God for human conduct. When challenging the universalist position about the possibility that, at the final judgement, some people may not have heard the preached gospel, it argues that all people live in the presence of the Son of God (Jacob 2002:105-106; Van Zyl 2013:118; Watson 1993:76). That is to say (Van Zyl 2013):

Even if you have not met him [Jesus Christ] in person, the anonymous Christ encounters you in his brothers - 'the least', the needy and the oppressed of the world. 'The least' are, therefore, not only objects of our compassion, but also subjects embodying the Son of man in whose presence we live. (p. 118)

Because the universalist position includes all people, Van Zyl (2013:114), Luz and Koester (2005:274) and Brown (2016:15-16) prefer it above the Christian and Jewish interpretations which are exclusive in nature, that is Christians and Jews will not be present at the final judgement by the Son of Man (Van Zyl 2013:114). This is also the position

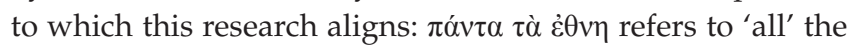
people. This essentially means that all people will face the judgement of the Lord, making it of utmost importance to have clarity of what the basis of judgement, according to Matthews, will be.

\section{Final judgement based on people's compassionate works to the vulnerable: Matthew 25:32b-46}

In Matthew 25:32b-33, those gathered before the throne are symbolised by two groups of animals, namely sheep and goats (Newman \& Stein 1988:782). Sheep represent the blameless (righteous) on the right-hand side of the Lord (Mt 25:34), whereas goats represent the wicked (unrighteous) on his left-hand side (Mt 25:33) (Newman \& Stein 1988). The passage further states that the Son of man (Mt 25:31) will come to judge humankind and place the blameless or righteous people into everlasting life (Mt 25:46, 34) and the wicked or unrighteous people into everlasting punishment (Mt 25:46).

The prerequisite for righteousness seats in whether people recognised the needs of the hungry and thirsty, also the homeless and poor, the sick and the imprisoned (Mt 25:35-36). The unrighteous are told to depart from the Son of Man and go into eternal punishment because they did not look after him when he was hungry, thirsty, sick, in prison, a stranger and naked (Mt 25:41-43). Brown (2016:9) notes the six actions for the righteous in Matthew 25:35-36, and for the unrighteous in Matthew 25:42-43, as the basis for the consequences accruing to both parties, the pivotal basis for judgement. These six deeds of mercy and compassion in Matthew 25:35-36 and Matthew 25:42-43 are traditionally also referred to in the Old Testament texts 
(i.e. Job 22:6-7; Is 58:6-7; Ezk 18:5-9) and Jewish literature (i.e. Tob 4:16-17, Sir 7:32-36, T. Jos. 1:5-7). However, it is important to note that 'the six moral characteristics listed in this passage are paradigmatic of Christian ethics' and not an extensive and definitive list of what Christ demands of his followers (Brown 2016:8).

What makes this prerequisite for righteousness truly challenging is that it seems as if Jesus regards this to be part of the very nature, or fibre, of Christian life. This becomes evident from the fact that the righteous will not 'know' when they have practised righteousness and the unrighteous when they did not (Van Zyl 2013:110-131). This state of unknowing for the righteous and unrighteous people is alluded to in the questions they will ask Jesus. Firstly, the righteous will ask Jesus when they had seen him in different states of destitution and attended to his needs (Mt 25:38). Secondly, the unrighteous will ask Jesus to indicate when they saw him in dire need, but refused to attend to him (Mt 25:44).

The true test of real charity is then also portrayed as something that needs to be extended to the 'least' persons. In this regard, Jesus uses himself as a point of reference, and thus charity towards him could be regarded as charity to the least of men. This comparison relates to the complete solidarity with Jesus displayed with the least members of the society of the time. In this regard, Van Zyl (2013) says:

These two groups will be judged according to their behaviour toward the Son of man. However, the Son of man identifies himself to such an extent with the 'least' that, in effect, it is the conduct toward the latter that forms the ultimate criterion of judgement. (p. 113)

Of particular interest for this article is why Jesus regards strangers as vulnerable people who should be invited into the homes of the more privileged. Morris (1992:637) and Arterbury (2007:21) portray a stranger, in the context of 1st-century Palestine, as someone who was 'always in a somewhat difficult position'. Morris (1992:637) argues that, during that era in Palestine, a person's plight in a foreign land or new region was extremely difficult because there were no - overnight - facilities. Arterbury (2007:21) adds that in the 1st century, travellers to new regions could not easily find hospitable reception, but rather fell victim to thieves and robbers (Arterbury 2007). This was worsened by the fact that natives viewed mysterious strangers as a threat and, therefore, 'sought to shun, abuse, or eliminate these outsiders before they could harm the community' (Arterbury 2007). It follows that even ordinary citizens were prone to harming strangers in the name of protecting themselves from any possible harm. Thus, Arterbury (2007:22) opines that the ancient world and the 1st-century period hospitality customs were designed to 'neutralise potential threats - both threats to strangers and threats to one's community'.

Morris (1992:638) and Arterbury (2007:21) undertake to develop the above-mentioned point as an attempt to establish the fundamental question in the 1st-century Palestine. In
Morris' (1992:638) view, the underlying question was about where a stranger could put up in an unfamiliar place, because there were no amenities, such as hotels and guesthouses that are used today. Likewise, in comparing the nature of hospitality in the New Testament and today's world, Arterbury (2007:21) concurs with Morris (1992) by arguing that today, we think of hospitality:

$[A] \mathrm{s}$ the custom of feeding family, friends, and [neighbours] in our homes or hosting these people for a night or two. The writers of the New Testament, however, were working with a significantly different definition of hospitality or xenia. The ancient custom of hospitality revolved around the practice of welcoming strangers or travellers into one's home while promising to provide them with provisions and protection. (p. 21)

However, Morris (1992:638) notes that although there are many lodging facilities today that a stranger or foreigner can use, these facilities cannot be easily accessed by vulnerable people because they cannot afford such accommodation. Now, in returning to the previously mentioned question, Morris (1992) interconnects the Old and New Testament cases by explaining that:

The Old Testament knows of a man who prepared to spend the night in the town square (Judges 19:15) ... If he was not to spend the night in the open air, someone would have to take him into a private home (Job 31:32). This was done among the Christians (Acts 10:23; Hebrews 13:2), who seem to have taken the duty of hospitality very seriously. (p. 638)

Morris (1992:638) substantiates his point by explaining that the word stranger also refers to a foreign person in a foreign land, who is largely known for lacking rights and protection. In paralleling the term stranger with alien or foreigner, Morris (1992) is correct because the Greek word $\xi \dot{\varepsilon} v o \varsigma$ (transliterated as xenos), as used in Matthew 25:35, can also be interpreted to mean 'alien or a foreigner' in English (Mounce n.d.:1). In Jesus' view, foreigners or aliens should be accorded love and hospitality. It is important to note that Jesus is not commanding Christians to only look after Christian strangers; instead, he wants them to exhibit compassion and love to all vulnerable people, regardless of their religion, ethnicity and nationality. This renders the identity of the 'least' in this passage also important.

\section{The meaning of 'the least of these brothers and sisters of mine' in Matthew 25:40 and 'the least of these' in Matthew 25:45}

Luz and Koester (2005:267-268) indicate that the phrases 'the least of these brothers and sisters of mine' in Matthew 25:40 and 'the least of these' in Matthew 25:45 have various interpretations. Luz and Koester (2005) categorise these interpretations as: universal, classical and exclusive. Mitch and Sri (2010:326) underscore that the universal and classical interpretation have taken prominence in the history of interpretation. Therefore, as we endeavour to understand the phrase 'the least of these brothers and sisters of mine' and 'the least of these' below, we will focus on explaining the classical and universalist interpretations. 


\section{The classical interpretation of Matthew 25:40 and Matthew 25:45}

The classical interpretation is also referred to as the ecclesiological interpretation by Van Zyl (2013:113). Pokorný (2001:154) also identifies it as a particularist interpretation. Brown (2016:14) notes that the evidence of the classical interpretation is derived from Matthew 12:46-50 (cf. Mt 28:10), in which the term brothers refers to Jesus' disciples. That is, when Jesus says in Matthew 25:40, the least of my brothers and sisters, he is referring to his followers as he has already done in Matthew 12:46-50. Brown (2016) further states that the advocates of the classical interpretation contend that the term least in Matthew 25:40 and 45 is the 'superlative' of 'little ones', which is often ascribed to Jesus' disciples in Matthew 10:42, 18:6, 10, 14 (Brown 2016). Van Zyl (2013:113) notes that in Matthew 10:40-42, Jesus refers to the disciples as the prophets, the righteous and the little ones. The phrase 'little ones' is also later on used in Matthew 18:6, 10, 14 to define those who believe in Jesus Christ (Van Zyl 2013). The proponents of the classical interpretation view Matthew 10:40-42 as corresponding with the scene described in Matthew 25 (Van Zyl 2013).

Further, the classical interpretation is championed by Claeys (2017:55-70), who argues that $\pi \alpha \dot{v} \tau \alpha$ $\tau \dot{\alpha} \dot{\varepsilon} \theta v \eta$ (all the nations) in Matthew 25:32 refers to the unbelieving gentiles who are being judged for their behaviour towards Jewish believers. At that material time, there were no Christians; instead, there were Jewish followers of Christ who were under tribulation (Claeys 2017). So the unbelieving gentiles will be judged on the basis of their behaviour towards the followers of Christ, although the believing Jews and gentiles will be vindicated (Claeys 2017). With this in mind, the proponents of the classical interpretation limit the least brothers and sisters of Jesus (Mt 25:40) and the least of these (Mt 25:45) only to Christian believers (Pokorný 2001:154). The above-mentioned notion of the least of these is also expressed by DeYoung and Greg (2011:162-163), who opine that the least of these refers to 'other Christians in need, in particular itinerant Christian teachers dependent on hospitality from their families of faith'.

Zhang (2016:19-20) argues that taking the 'least of these brothers and sisters of mine' (Mt 25:40) and the 'least of these' (Mt 25:45) to refer to specific Christians in need 'is not in accordance with the four Gospels and the whole Scripture, in which the poor and the oppressed are always loved'. In scripture, Jesus takes care of the vulnerable people, regardless of their religious, cultural and ethnic backgrounds (Zhang 2016).

\section{The universal interpretation of Matthew 25:40 and Matthew 25:45}

The universal interpretation argues that the phrases 'the least of these brothers and sisters of mine' (Matt. 25:40) and 'the least of these' (Mt 25:45) refer to all people in need, including Christians and non-Christians (Luz \& Koester 2005:267-268). Stanley and Baker (2006:303) state that the proponents of the universalist interpretation affirm that the term brother in Matthew 25:40 can mean the same as neighbour in Matthew 5:22, 23, 24, 47, 7:3, 4, 5. Also, the phrase least of these is consistent with Matthew 22:37-40, in which Jesus teaches the lawyer about the greatest commandment. In Matthew 22:37, Jesus advises the lawyer that the greatest commandment is for him to love God with all his heart, soul and mind, and the next (Mt 22:9) is to love his neighbour as he loves himself. Brown (2016:13) argues that the proponents of universalist link Matthew 22:37-40 with Matthew 25:31-46, which consequently implies that in Matthew 25:31-46 Jesus will judge people on the basis of their faithfulness to these two commandments that sum up the Old Testament Law.

Brown (2016:14-16) is discontented with the manner in which the universal interpretation proponents link Matthew 22:37-40 and Matthew 25:31-46 because 'rather than [the] love of God preceding and dictating [the] love [of one's] neighbour, [the] love of God is interpreted as the love of one's neighbour'. Brown (2016) then proposes a new interpretation that argues that people from all the nations (Christians and non-Christians) will be amongst the sheep and the goats at the final judgement. The Son of Man will not hold nonChristians accountable for how they cared for the least of Jesus' disciples (Mt 25:40) (Brown 2016). Instead, Christians are the ones that will be held accountable for how they cared for their fellow Christians that were in need (Brown 2016). Non-Christians will be held accountable for the manner in which they took care of their fellows' needs (Mt 25:45) (Brown 2016). However, we are glad that Brown (2016:17-18) acknowledges the weakness of his new interpretation when he argues that it contradicts Matthews's teaching about loving one's enemy and the needy, whether they are of the Christian faith or not. We concur with Brown (2016:18) because the New Testament seems to elevate those who are in the household of faith without encouraging the neglect of the needy in general, as Galatians 6:14 and John 15:9-17 attest.

Zhang (2016:3-17) is another scholar who subscribes to the universalist interpretation. Zhang (2016:17-18) argues from a Christological perspective emerging from Matthew 25:40 and 45 that the phrases 'least of these brothers of mine' (Mt 25:40) or 'the least of these' (Mt 25:45) refer to all needy people, regardless of their religious background. Zhang (2016) proposes two kinds of Christology that arise from Matthew 25:31-46, namely the glorious and suffering Christology (Zhang 2016). In Mathew 25:31, Jesus is the glorious Christ, whereas in Matthew 25:40 and 45, he is the suffering Christ. The glorious Christology arises from Matthew 25:31 that titles Jesus as 'the Son of Man', king or judge, who will sit on his glorious throne and gather people from all the nations to judge them (Zhang 2016:14). The suffering Christology arises from Matthew 25:40 and 45 that reveal Jesus Christ as a divine judge who identifies with the poor (Zhang 2016:16). In Van Zyl's (2013) view, when Jesus refers to the needy as 'the 
least of these brothers and sisters of mine' (Mt 25:40) and 'the least of these' (Mt 25:45), he is underscoring the notion that he is a suffering servant who identifies with the vulnerable, such as strangers (Donahue 1986:18; Zhang 2016:16).

Likewise, Mitch and Sri (2010:326) observe that the phrases 'the least of these brothers and sisters of mine' (Mt 25:40) and 'the least of these' (Mt 25:45) imply to all underprivileged people, irrespective of their religious beliefs, as intrinsic in the incarnational mystery, in which the infinite, transcendent and compassionate God in and through Christ identifies with all people, including those who are vulnerable as bearers of the divine image (Mitch \& Sri 2010:326). Hence, Mitch and Sri (2010) state:

While 'these least brothers of mine' may be understood as Christian disciples, there is a long tradition of identifying them as all people in need. According to this interpretation, Jesus expresses his identification not only with those who have become his followers (his brothers and sisters in the sense of his followers) but with every human person who suffers and is in need of compassion (his brothers and sisters in the sense of all fellow human beings). After all, Jesus does identify in a special way with the poor and underprivileged, regardless of their age, sex, nationality, or creed. Being their creator, his image is pressed upon every living person (Genesis 1:27). (p. 326)

\section{Hebrews 13:1-2: Love as a permanent characteristic of the kingdom of God that is practically expressed by Christians' hospitality to strangers ${ }^{5}$}

There is consensus amongst scholars such as Phillips (2006:588), Peitzner (1997:191), Thompson (2008:278), Schaeffer (1982:4183) and Koester (2001:563) in viewing Hebrews $13: 1-2$ as one of the fundamental texts that challenge the church of God to persevere with care for strangers despite the challenges it presents.

Hagner (2005:247) and Phillips (2006:586) understand that Hebrews was written to early Jewish Christians who suffered persecution in Jerusalem to encourage them to endure with their Christian calling. Possibly, the persecution they faced caused some of them to consider forsaking their Christian convictions. In agreement with Craddock (1998:9), it can be posited that although these Jewish Christians might not have gotten to the point of dying for their faith in Christ (Heb 12:4), it is discernible that they experienced a lot of suffering, as Hebrews 10:34 stipulates that some of them were subjected to imprisonment and confiscation of their property. Together with Craddock (1998:9), we understand that the extent of

5.This discussion is not exhaustive, however, it only seeks to highlight God's command for believers to look after strangers, regardless of the challenges they encounter. For a detailed discussion of this passage, one should study Magezi's (2018:105-110) a detailed discussion of this passage, one should study Magezi's (2018:105-110) work, which presents a detailed discussion of Hebrews 13:1-2 in the light of the contemporary complex situation of migration. Magezi (2018) argues that Hebrews $13: 2 \mathrm{~b}$, by inference, refers to the stories of Abraham and Sarah in Genesis 18:1-15 and Lot in Genesis 19:1-29, to motivate Christians to continue acts of hospitality to strangers, in spite of the cost incurred. According to Magezi (2018), from the allusion to Abraham and Sarah's story, one can also perceive that the act of hospitality is closely associated with God's blessings. the suffering of Jewish Christians is intensified when the author of Hebrews provides a vivid picture of their plight by employing the following words: 'persecution' (Heb 10:33), 'hostility' (Heb 12:3) and 'torture' (Heb 13:3) (Craddock 1998:9). However, Phillips (2006:587) argues that, one of the unique contributions of Hebrews is that these Jewish Christians are encouraged to hold firm to their Christian duties such as showing hospitality to strangers, in spite of the challenges they experienced (Heb 13:1-2).

A plea for these Christians to continue practising their Christian duties, such as hospitality to strangers (Heb 31:2), in spite of the suffering, torture and hostility they experienced, is benchmarked by Hebrews 13:1, which begins with a command for the persecuted Christians to continue with brotherly love. Here, it is certain that love for fellow Christians or one another should not be compromised by challenges; instead, it should continue to be demonstrated (Peitzner 1997:191; Phillips 2006:587). It can be postulated that the encouragement for Christians to continue exercising brotherly love is intertwined with Hebrews 12:27-28, which reveals the aspect of God's steadfast kingdom that will live forever (Peitzner 1997:191). The connection between Hebrews 13:1 and Hebrews 12:27-28 presents brotherly love as one of the enduring Christian characters (timeless Christian character) of the kingdom of God that Jewish Christians have to continue practising in the face of hardships. The command for brotherly love in Hebrews 13:1 echoes Jesus' command to his disciples to continue loving one another as Christ loved them (Jn 15:12; Phillips 2006:586). That is, as recorded in John $15: 12$, when Jesus knows that his arrest by the temple guards of the Sanhedrin is imminent, one of the last things he commands his disciples to do is to continue their love for one another as he had demonstrated to them.

After commanding the Jewish Christians to continue with brotherly love (in Heb 13:1), in spite of their own challenges, the author of Hebrews proceeds to exhort Christians to continue their duty of hospitality to strangers (Heb 13:2). Unfortunately, there is no evidence from the text that shows that the hospitality that the audience of Hebrews are exhorted to continuously practise should be indiscriminately applied to all strangers, whether they are fellow Christians or nonChristians. However, as we have argued in the above analysis of Matthew 25:31-46, we disagree with any opinion that suggests that the author of Hebrews is calling on Jewish Christians to practise hospitality to Christian strangers alone. This is because the New Testament seems to elevate service towards those that are in the household of faith without encouraging the neglect of the needy in general, as Galatians 6:14 and John 15:9-17 attest (Brown 2016:18). This is substantiated by Koester (2001:563) and Arterbury (2007:22), who reveal that in the 1st-century and Greco Roman worlds, Christians extended their hospitality to non-Christians.

One of the main thrusts of Hebrews 13:2 is to urge Christians to welcome the stranger as an important act of Christian hospitality (Koester 2001:563; Phillips 2002:588). Hebrew 
Christians are exhorted to do so regardless of the possible harm it can incur (Koester 2001:563; Phillips 2002:588). However, one should point out that during the 1st-century period, there were precautions to protect ordinary people from hosting suspicious-looking strangers, some of whom were armed or possessed magical powers (Arterbury 2007:21). The '... leading citizens of a community often bore the primary responsibility for hosting' the magical and militarily equipped strangers (Arterbury 2007).

\section{Discerning theological principles for sacrificial migrant ministries in complex migration situations}

Emerging from the discussion of Matthew 25:31-46 is the notion that the churches should develop migrant ministries that recognise that God's will for all human beings, including Christians and non-Christians, to look after all vulnerable people, in their communities (Van Zyl 2013:116). Further, Matthew 35:31-46 also dissuades Christians from limiting their practice of love to vulnerable fellow Christian migrants. Instead, the proposed text expects Christians to care for all vulnerable people in and outside the church. The aforesaid understanding has far-reaching implications because it challenges churches to develop migrant ministries that address the complex needs and challenges of migrants that are in both church and non-church spaces because the love of Christians should not be limited to vulnerable fellow migrant Christians. This point is encapsulated in one of the Vatican Council's II familiar documents, Gaudium et Spes, which applies Matthew 25:31-46 in the ensuing manner ( $\mathrm{O}^{\prime}$ Brien \& Shannon 2010):

In our times a special obligation binds us to make ourselves the neighbour of absolutely every person, and of actively helping him when he comes across our path, whether he be an older person abandoned by all, a foreign labourer unjustly looked down upon, a refuge ... a hungry person who disturbs our conscience by recalling the voice of the Lord: As long as you did it for one of these, the least of my brethren you did it for me (Matthew 25:40, 45) [\#27]. (p. 119)

The above-mentioned conception is further substantiated by the suffering Christology of Matthew 25:40 and 45, in which Jesus indicates that he identifies with all vulnerable people, including Christians and non-Christians as the bearers of his image (Mitch \& Sri 2010:326). Jesus cares for all vulnerable people (i.e. Christian and non-Christians) to the extent that he measures service to himself by how Christians and non-Christians serve the lowly people in their communities and societies. For instance, Jesus expects all people to address the needs or challenges of vulnerable migrants. With the preceding notion in mind, one can argue that Matthew 25:31-46 should operate as a springboard in also challenging non-Christians to care for vulnerable people from different backgrounds, as God also expects them to practise empathy and compassion to all vulnerable people, including migrants.
Stated differently, Matthew 25:31-46 calls the church to challenge non-Christians to care for vulnerable migrants by making them conscious of the actuality that God expects them to care for the lowly people amongst them. This is because the well-being and safety of vulnerable migrants depend on the love and care of other people. The preceding notions are able to assist the churches to mobilise nonChristians to act in care, compassion and love for vulnerable migrants, as God expects them to do. In doing this, there will be a collective effort between Christians and non-Christians in embracing migrants and fighting for their (migrants') well-being in all aspects of life. That is to say, when the church mobilises non-Christians to care for vulnerable migrants in their communities and beyond, the church itself will effectively accomplish its role in caring for vulnerable migrants the world over. Van Zyl (2013:116-117) supports the aforesaid conception in noting that Matthew 25:31-46 reveals that the actions of compassion that are expected of the followers of Christ are also the expression of God's will for all people. In saying this, we expect the church to take a leading role in caring for vulnerable migrants. This is inbuilt in the conception that (Mitch \& Sri 2010):

[I]f the works of charity and compassion are expected of nonChristians, how much more are the followers of Jesus expected to put love into action through service to others. (p. 326)

Additionally, Jesus pronounces that the eschatological judgement of all people (Christian and non-Christians included) from all nations will be on the basis of how they treated the lowly amongst them (Mt 25:32). This is crucial in challenging churches to develop sacrificial migrant ministries. Matthew 25:31-46 reveals that Christians and non-Christians will be equally subjected to the judgement of God and their actions towards the lowly will determine the resultant reward or condemnation. In our view, the overriding notion in this instance is the interplay of the fear of God's judgement and responsibility compulsion in Matthew 25:31-46, which should operate as the nexus for encouraging churches to implement responsible migration responses (Magezi 2019). Christians should be fully aware that the judgement of God for all people takes into consideration how they treat the lowly. Such knowledge would result in deeper understanding that the vulnerable people are very important before God. Likewise, the church and, consequently, Christians should consider the vulnerable as important before God and act according to expression of God's will for human conduct that is looking after the migrants.

Finally, the timeless message of Hebrews 13:1-2 challenges the church and, consequently, Christians to develop sacrificial migrant ministries that practise hospitality to strangers, regardless of the dangers that could befall them whilst they are undertaking these acts of hospitality. In the contemporary world, where there is a paradox of inclusivity and exclusivity of migrants, because of the dangers they can pose to the natives of host nations, Hebrews 13:1-2 presents love as a permanent character of the kingdom of God that Christians should practically exhibit in their societies, regardless of 
the challenges they face when responding to migrants' challenges. That is, Christians should pursue their Christian obligation to love strangers, in spite of the risks that their loving and compassionate acts may attract. This entails the need to overlook the aliens' statuses and all the other challenges they can pose to the hosting nations and their citizens. This means that although the contemporary situation of migration is complex and sometimes costly to the citizens (Christians and non-Christians) of the hosting nations (just like how it was dangerous for the ancient Jewish in the Graeco-Roman period to host strangers with mixed motives); Christians everywhere are challenged to strive to be hospitable to strangers in various ways. This calls for Christians and the church to practise sacrificial love for migrants by sacrificing their material resources, time and life for the well-being of migrants.

However, just like the antiquity and early church period, the current churches should develop sacrificial migrant ministries that take precautions to secure its members and the general public from any harm that may arise from some migrants' harmful behaviours and attitudes. In our view, the precaution should constitute reporting suspicious migrants to nongovernmental and governmental organisations that deal with migration issues for assistance because they might have the power, capacity and experience to deal with suspicious migrants. Here, we are challenging the church to integrate other stakeholders in assisting it to address the complex issues of migrants that are beyond its capacity and jurisdiction. This notion corresponds with the World Economic Forum's (2017:145) understanding that there is no single entity, government or organisation that can deal with the complex issue of migration alone; instead, we need efforts from various stakeholders to combat migration issues and challenges.

\section{Conclusion}

This article upholds that migration will continue to pose complex challenges for migrant-hosting nations and their citizens in ways that culminate in the paradox of inclusivity and exclusivity of migrants. However, the church, as the distinct community that is the embodiment of God in loving and caring for the vulnerable in this interim period of Christianity, should continue to develop sacrificial migrant ministries that exhibit compassionate and loving character by responding to migrants' challenges, despite the cost and risks that are embedded in such a mandate.

\section{Acknowledgements Competing interests}

The authors declare that they have no financial or personal relationships that may have inappropriately influenced them in writing this research article.

\section{Authors' contributions}

A.R.B. and C.M. contributed equally to this research article.

\section{Ethical considerations}

This article followed all ethical standards for research without direct contact with human or animal subjects.

\section{Funding information}

This research received no specific grant from any funding agency in the public, commercial or not-for-profit sectors.

\section{Data availability statement}

Data sharing is not applicable to this article as no new data were created or analysed in this study.

\section{Disclaimer}

The views and opinions in this article are those of the authors and do not necessarily reflect the official policy or position of any affiliated agency of the author.

\section{References}

African News Agency, 2020, 'Refugee group leader arrested for assault at Cape Town church', The South African, viewed 06 January 2020, from https://www. thesouthafrican.com/news/cape-town-refugee-leader-arrested-1-january-2020/.

Amit, R., 2017, African refugees in South Africa are often unable to access their rights, viewed 06 January 2019, from http://blogs.Ise.ac.uk/africaatlse/2016/01/29/ african-refugees-in-south-africa-are-often-unable-to-access-their-rights/.

Arterbury, A., 2007, Entertaining Angels: Hospitality in Luke and Acts, viewed 07 April 2020, from https://www.baylor.edu/content/services/document.php/53378.pdf.

Brown, T., 2016, 'Exegesis of Matthew 25:31-36 with an emphasis on the identity of all the nations and the least of these', Academia, viewed 31 March 2020, from https://www.academia.edu/34353125/Exegesis_of_Matthew 25_31_46_with an_Emphasis_on_the_Identity_of_All_the_Nations_and_the_Least_of_These_.

Claeys, J., 2017, 'Matthew 25:31-46', Journal of the Grace Evangelical Society 30(59), 55-70.

Coetzee, J., 2019, 'Prejudice against immigrants cuts across class and race', Mail \& Guardian, viewed 08 January 2020, from https://mg.co.za/article/2019-09-05 prejudice-against-immigrants-cuts-across-class-and-race.

Craddock, F.B., 1998, The new interpreter's Bible: The letter to the Hebrews, Abingdon, Nashville, TN.

Cuterela, S., 2012, 'Globalisation: Definition, process and concepts', Revista Română de Statistică - Supliment Trim IV, pp. 137-146, viewed 28 June 2019, from http:// www.revistadestatistica.ro/suplimente/2012/4/srrs4_2012a22.pdf.

DeYoung, K. \& Greg, G., 2011, What is the mission of the church? Making sense of social justice, shalom and the great commission, Crossway, Wheaton, IL.

Donahue, J.R., 1986, "The "parable" of the sheep and the goats: A challenge to Christian ethics', Theological Studies 47(1), 3-31. https://doi.org/10.1177/0040563 98604700101

Gray, S., 1989, The least of my brothers: Matthew 25:31-46: A history of interpretation, Scholars Press, Atlanta, GA.

Greene, R.A., 2016, ' 3800 dead ... and more on the way', CNN, viewed 28 June 2019, from https://edition.cnn.com/2016/10/26/europe/mediterranean-migrant-crisisvisual-guide-trnd/index.html.

Hagner, D.A., 2005, 'The Son of God as unique high priest: The Christology of the epistle to the Hebrews', in R.N. Longenecker (ed.), Contours of Christology in the New Testament, pp. 247-267, William B. Eerdmans, Grand Rapids, MI.

Heleta, S., 2018, 'How many immigrants live in South Africa?', viewed 09 January 2020, from https://africasacountry.com/2018/10/how-many-immigrants-live-insouth-africa.

Hood, J., 2009, 'Matthew 23-25: The Extent of Jesus' Fifth Discourse', Journal of Biblical Literature 128(3), 527-543. https://doi.org/10.2307/25610201

Human Rights Watch, 2014, Kenya: Halt crackdown on Somalis, viewed 20 November 2019, from https://www.hrw.org/news/2014/04/11/kenya-halt-crackdownsomalis.

Jacob, E.M., 2002, 'Discipleship and mission: A perspective on the Gospel of Matthew', International Review of Mission 91(360), 102-110. https://doi.org/10.1111/j.1758 6631.2002.tb00332.x

Kiewit, L., 2019, 'Refugees allegedly assault religious leaders, human rights officials in Cape Town', Mail \& Guardian, viewed 08 January 2020, from https://mg.co.za/ article/2019-11-15-refugees-allegedly-assault-religious-leaders-human-rightsofficials-in-cape-town.

Koester, G.R., 2001, Hebrews: A New translation with introduction and commentary, Yale University, New Haven, CT. 
Langer, M., 2020, 'Cape Town refugee group leader arrested', News24, viewed 06 January 2020, from https://www.news24.com/SouthAfrica/News/cape-townrefugee-group-leader-arrested-20200101.

Lidák, J., 2014, 'International migration, Europe and migration from Africa', Asian and African Studies 23(2), 226-254.

Louw, D., 2016, 'The refugee dilemma and migrant crisis: "Charity begins at Home" or "Being Home to the Homeless"? The paradoxical stance in pastoral caregiving and the infiltration and perichoresis of compassion', HTS Teologiese Studies/ Theological Studies 72(2), a3267. http://dx.doi.org/10.4102/hts.v72i2.3267

Luz, U. \& Koester, H., 2005, Matthew 21-28: A commentary, Augsburg Fortress, Minneapolis, MN.

Magezi, C., 2018, 'Theological understandings of migration and church ministry model: A quest for holistic ministry to migrants in South Africa', PhD thesis, NorthWest University.

Magezi, C., 2019, 'Interplay of fear of God's judgement and responsibility compulsion as nexus for encouraging responsible migration response', Verbum et Ecclesia 40(1), a1909. https://doi.org/10.4102/ve.v40i1.1909

Martin, J.P., 2008, 'Migration and the global economy: Some stylised facts', viewed 28June 2019, from citeseerx.ist.psu.edu/viewdoc/summary?doi=10.1.1.517.9986

Mitch, C. \& Sri, E., 2010, The gospel of Matthew: Catholic commentary on sacred Scripture, Baker Academic, Grand Rapids, MI.

Monsma, T.M., 2000, 'The urbanisation of our world', in R.S. Greenway \& T.M. Monsma (eds.), Cities: Missions' new frontier, pp. 13-23, Baker Academic, Grand Rapids, MI.

Morris, L., 1992, The gospel according to Matthew, William B. Eerdmans, Grand Rapids, MI.

Mounce, P. B., n.d., 〔́́voc, viewed 16 July 2019, from https://www.billmounce.com/ greek-dictionary/xenos.

Newman, B.M. \& Stein, P.C., 1988, The gospel of Matthew, United Bible Societies, New York, NY.

O'Brien, D. \& Shannon, T.A. (eds.), 2010, Catholic social thought: The documentary heritage, Orbis Books, Maryknoll, NY

Onaedo, E., Samuel, O. \& John, S., 2017, 'An assessment of the impact of internal displacement on human security in northern Nigeria (2009-2016)', Acto Universitatis Danubius 10(1), 19-42.

Organisation for Economic Co-operation and Development (OECD), n.d., Globalisation transport and the environment', viewed 28 June 2019, from https://www.oecd. org/greengrowth/greening-transport/45095528.pdf.
Peitzner, V.C., 1997, Hebrews: Abingdon New Testament commentaries, Abingdon Press, Nashville, TN.

Phillips, R.D., 2006, Hebrews: Reformed expository commentary, P\&R Publishing, Phillipsburg.

Pluncinska, J., 2015, The Paris attacks have put Europe's refugee crisis under renewed scrutiny, viewed 27 May 2016, from https://time.com/4114009/paris-attacksmigrant-crisis-refugees-eu/.

Pokorný, P., 2001, 'Matth 25, 31-46 und die Globalisierung christlicher Ethik', Communio Viatorum 43(2), 153-158.

Schaeffer, F.A., 1982, The mark of the Christian, Crossway, Wheaton, IL.

Shoba, S., \& Tobias, N., 2019, UNHCR urges refugees to stay in South Africa, despite their circumstances, viewed 08 January 2020, from https://www.dailymaverick. co.za/article/2019-11-06-unhcr-urges-refugees-to-stay-in-south-africa-despitetheir-circumstances/.

Stanley, A. \& Baker, D., 2006, Did Jesus teach salvation by works? The role of works in salvation in the synoptic gospel, Wipf and Stock Publishers, La Vergne, TN.

Sturm-Martin, I., 2014, Migration in European history, European University Institute, viewed 28 June 2019, from https://www.eui.eu/Documents/RSCAS/ PapersLampedusa/FORUMSturm-Martinfinal.pdf.

Thompson, J.W., 2008, Hebrews, Baker Academic, Grand Rapids, MI.

Turner, D.L., 2008, Matthew: Baker exegetical commentary on the New Testament, Baker Academic, Grand Rapids, MI.

Van Lennep, T., 2019, Migration I: Public opinion versus reality on immigration in South Africa, viewed 08 January 2020, from https://www.politicsweb.co.za/ opinion/migration-i-public-opinion-versus-reality-on-immig.

Van Zyl, V.H.C., 2013, 'Discernment as not knowing and knowing a perspective from Matthew 25:31-46', Acta Theologica 32(Suppl. 17), 110-131. https://doi.org/10. 4314/actat.v32i2S.6

Watson, F., 1993, 'Liberating the reader: A theological-exegetical study of the parable of the sheep and the goats (Matt 25:31-46)', in F. Watson (ed.), The open text: New directions for Biblical Studies, pp. 57-84, SCM Press, London.

World Economic Forum, 2017, Migration and its impact on cities, viewed 28 April 2020, from http://www3.weforum.org/docs/Migration_Impact_Cities_report 2017_HR.pdf.

Zhang, R., 2016, 'Matthew's least brothers and it's application in the Catholic church', MA thesis, Saint John's University. 